\title{
Protection of the Cultural Heritage from Under- ground Metro Vibration and Ground-Borne Noise in Athens Centre: The Case of the Kerameikos Archaeological Museum and Gazi Cultural Centre
}

\author{
Konstantinos Vogiatzis \\ University of Thessaly, Department of Civil Engineering, Pedion Areos, 38334 Volos, Greece
}

\section{(Received August 8, 2011, Accepted December 8, 2011)}

This paper describes the assessment, implementation and verification of the necessary mitigation measures for the protection of the Hellenic cultural heritage of the Kerameikos Museum and archaeological area and the Gazi Cultural Centre in Athens centre from vibration and ground-borne noise during the operation of underground Metro line 3 (Monastiraki to Egaleo). The aim of this article is to present a state-of-the-art assessment and evaluation, through an extended measured program, of the behavior of the implemented mitigation measures in each sensitive archaeological artifacts in the area along the extension alignment. In order to reach this objective, the relevant Athens Metro line section was divided into homogeneous sections (i.e., sections along which the tunnel and soil types, depth and distance from nearby buildings, and presence or not of a switch were considered as constant). Particular emphasis was placed on sections in direct contact with the most important archaeological artifacts, such as the museum and other relevant cultural uses. Data from the relevant prediction model were evaluated on the basis of a complete measurement campaign during Metro operation in the area. The implemented fully floating slab solution, according to the measurement results during Athens Metro operation, recorded levels of groundborne noise and vibration well within the severe criteria imposed for the Kerameikos area and Museum (as well as for the Gazi Cultural Centre and radio station), both at soil surface locations and on marble statues and various artifacts on glass shelves in the Museum.

\section{INTRODUCTION}

The following extensions, for lines 2 and 3 of Athens Metro, presented in Fig. 1, were executed recently and are already in full operation:

- extension of line 2 from Dafni to Ilioupoli,

- extension of line 3 from Ethniki Amyna to Stavros,

- extension of line 3 from Monastiraki to Egaleo,

- extension of line 2 from Sepolia to Thivon, and

- extension of line 3 Egaleo-Haidari (under final stage of construction).

The purpose of this paper and the relevant research, is the protection of the cultural heritage in the case of the Kerameikos Archaelogical area and Museum (see Fig. 1) as well as the Gazi Cultural Centre in Athens centre from underground Metro vibration and ground-borne noise due to the operation of the extension of line 3 from Monastiraki to Egaleo, with regard to extremely sensitive receptors (see Fig. 2):

- Gazi music room and exhibition centre, Theater and concert hall and Gazi radio station,

- archaeological area and Museum of Kerameikos (chainage 4+700-chainage 4+880)

The "Kerameikos" area was named after the community of potters who worked within the city walls and occupied the area along the banks of river "Eridanos." The "Kerameikos" archaeological site is better known nowadays as the most important cemetery of ancient Athens. Inner "Kerameikos," within the city walls, was used for urban development, while the area outside the walls was used for burials. The two most important gates of Athens stood here: the "Dipylon," through which passed the road, or "'Dromos," to Plato's Academy, and the "Sacred Gate" with the road to Elusis. The "Sacred Gate" is associated with the festivities of the Eleusinian Mysteries. At "Dipylon" the procession of the Panathenaian festival assembled before ascending to the "Akropolis." During the Classical period $\left(5^{\text {th }}-4^{\text {th }}\right.$ century BC), the "Street of Tombs" and "Dromos" were surrounded by funerary monuments. Outside "Dipylon," by the road to Plato's Academy, the public cemetery for prominent Athenians and for those who fell in the war was established. From the Hellenistic period to Early Christian times (338 BC to $6^{\text {th }}$ century AD), the "Kerameikos" cemetery continued to function in the same place. The archaeological site, an area of some $40,000 \mathrm{~m}^{2}$ in extent, was covered by an alluvial fill of 8-9 $\mathrm{m}$ deep, which reached the level of today's "Ermou Street." The fully restored Museum, houses valuable collections of beautiful steles, sculptures, vases and terracotta figurines unearthed from the site, which are extremely sensitive to vibration.

The Gazi Cultural Centre (Technopolis), on the other hand, is an industrial museum and a major cultural venue of the City of Athens. The Centre is located in the neighborhood of Gazi, next to the Kerameikos archaeological area, and very close to the Acropolis. It is dedicated to the memory of the great Greek composer Manos Hatzidakis, which is why it is also known as the "Gazi Technopolis Manos Hatzidakis." It has been in operation since 1999 and is situated in the city's former gasworks, which were founded in 1857 and occupy an area of 